\title{
Women, Patronage, and Self-Representation in Islamic Societies
}

Ruggles Fairchild (editor), Albany: State University of New York Press, 2000.

The aim of the authors in this book was to provide a supplementary text for studies on gender issues in Islamic societies. Ruggles Fairchild (editor) notes that a more significant aim of the book was to broaden not only the geographical realm but the scope and the time frame of analysis of the studies on gender in Islamic societies. This book examines the implicit economic, social and political influence of elite Muslim women in their respective societies by shedding light on the women's patronage of architecture, clothing and art. Authors argue that such visible expressions - products of women who were otherwise invisible in society were, and are, reflective of women's implicit agency (means of exerting power in society) in ancient Islamic societies. The main premise of the authors is that while women have been absent in the explicit representation (depiction) of art, architecture and society, they have in fact been very much present in the background of these realms of Islamic society.

While other studies of gender have emerged from consideration of social, economic and political structures in Muslim societies, few (if at all, argue the authors) have emerged from an examination of "visual arts" or "visual culture" ( $p$. 2). This is the void the book seeks to fill. In this sense this book is very important, as it sheds light on the subtle agency of women in ancient Islamic societies and challenges the stereotypical notion that women were (are) subservient, muted entities in Islamic societies (past or present). In their challenge of the stereotypical view of Muslim women in ancient Islamic societies, the authors also question the 
very definition and understanding of the concept of 'power'. Women, who have traditionally been considered 'powerless' in ancient Muslim societies, were in fact the patrons of architecture, and owners of luxury goods, textiles and books, argue the authors. It is this dichotomy between the absence of conventional political power (for example the presence of women in governing bodies) and the presence of indirect avenues for exerting political, social and economic influence by women in ancient Islamic societies that forms the basis of this book. Such a focus beckons the reexamination of the term 'power' from the context of ancient Muslim societies.

Yasser Tabbaa, in the chapter entitled Dayfa Khatun, Regent Queen and Architectural Patron, concentrates on "patronage of some women of the Ayyubid court (1174-1260)" and on the "architectural patronage of the Dayfa Khatun in Aleppo in the 1230s" (p. 18). Tabbaa argues that the "princesses of the Zengid and Ayyubid dynasties of Upper Mesopotamia, Syria, and Egypt commanded a great deal of respect and a royal status rarely accorded to court women before them," despite the fact that "their person was hidden from views by veils" (p. 19). Three factors explain this phenomena according to the author: (1) the women in question were princesses and thus not slaves and/or concubines; (2) Ayyubid princesses often had political marriages and thus enjoyed the protection and prestige of their natal families; (3) the birth of males granted further prestige to princesses since the birth of sons was essential to the continuation of the dynasties.

The marriage of Dayfa Khatun- the focus of the author's analysis- to Ghazi in Aleppo in 1212 resulted in the birth of a male a year later, elevating Dayfa's status. After the death of Ghazi in 1216, Dayfa became the sovereign of an Islamic state. However, Dayfa "walked a fine line between her de facto sovereignty and her de juris position as simply the grandmother and advisor of the future sultan" (p. 22). Sufi convents and mausoleums were attributed to Dayfa's architectural patronage. The important point here, argues the author, is that Dayfa's architectural patronage was not an exception but the rule among the Ayyubid court women. In fact, Tabbaa notes that a quarter of all madrasas and a fifth of all religious structures were founded by women. Another interesting fact to note is that, of the structures founded by Dayfa, the inscription on one of them does not name her directly, while the inscriptions on the other do name her in person. Hence, in reality, Dayfa was far more influential in her times than is apparent at first glance.

Ethel Sara Wolper, in the chapter entitled Princess Safwat al-Dunya wa al-Din and the Production of Sufi Buildings and Hagiographies in Pre-Ottoman Anatolia, analyses the frequent references to the princess in Sufi building inscriptions. Indeed, the author's focuses on the question of why females were so 
popularly referred to (either with their names or their titles) in Sufi buildings, since the inscriptions required a permission of the quadi (judge). Though such inscriptions undoubtedly conveyed an important public message, argues the author, a more intriguing question is 'what was that message'? Wolper focuses on the latter question, since she believes that simple naming of women was "not necessarily a sign of power" (p. 47).

The inscriptions were perhaps an indication of the "newly formed dynastic and political alliances" argues the author (45). In order to understand the latter, the author points to the importance of keeping in mind the role that women played in continuing dynasties through procreation and, more significantly, the birth of sons. In analyzing the inscriptions naming princess Safwat al-Dunya on the Sunbul Baba lodge, the author concludes that "her name was of critical importance in the lodge's inscription, for it provided a genealogical bridge between past and present and thus united the Sunbul Baba lodge with the venerable Rumi" (p. 48). This points to the social importance of the women in the society and, more importantly, the social prestige associated with women.

Leslie Peirce, in the chapter entitled Gender and Sexual Propriety in Ottoman Royal Women's Patronage, asks the question, "How is a woman's gender a significant factor in determining what forms of patronage are accessible to her?" And, more importantly, she asks "[i]f patronage is an index of one's status within hierarchies of power, what distinguishes one female patron from another?" (p. 53). In examining royal patronage of women in the Ottoman dynasties, Peirce notes that the nature and determinants of patronage changed throughout the life of a woman. When a woman was in her child-bearing age, her power and influence was based on her status as mother. However, when a woman became an 'elder' (either because she was no longer of use to the Saltan since she had already born him a son, or because she practiced abstinence or was in her years of menopause), her power and influence was based on her architectural endowments. Such endowments "granted public stature and influence to the female elder" (p. 56). One of the most important facts that the author highlights in this chapter is that "the female patron's identity was independent of a martial or sexual lineage with a male" (p. 56). Public opinion was important in the approval of both forms of patronage. Peirce concludes that, "The Ottoman case suggests that gender should be understood not as an essentializing category of analysis ("female patronage"), but rather as a dynamic and nuanced element in the religiously, socially, and politically complex act of patronage in Islamic societies" (p. 66).

Lucienne Thys-Senocak, in the chapter entitled The Yeni Valide Mosque Complex of Eminonu, Istanbul (1597-1665): Gender and Vision in Ottoman Architecture, examines the architectural design of the Yeni Valide mosque complex which, the author points out, "is a large pious foundation located on the shores of the Golden 
Horn in the Eminonu district of Istanbul" (p. 69). Thys-Senocak notes that the "Yeni Valide complex reflected the efforts of two powerful dynastic women" (p. 72). While acknowledging the fact that such patronage by women was not unusual in the Ottoman dynasties, the author examines the role that the gender of the patrons played in the location, design and organization of the structure. Through a most interesting analysis, supplemented by intriguing photographs, the author concludes that "the skillful manipulation of the built environment, the valide extended the space and stage upon which she could exercise her authority and brought gender as a nuanced and important factor into the 'optical politics' of the Yeni Valide complex and the Ottoman architectural enterprise" (p. 86).

Ellison Banks Findly, in the chapter entitled Women's Wealth and Styles of Giving: Perspectives from Buddhist, Jain, and Mughal Sites, examines the many different ways in which women in South Asia were patrons of architecture (specifically of monuments). Though Findly begins the chapter with a very captivating account of the patronage of the Mugal queen Nur Jahan, she points out that Nur Jahan was not alone in such acts of 'dana' (donation). Hence, she states that "the matronage of a queen like Nur Jahan was not a singular activity but one which had as its larger context many sectors: householder women giving to Buddhist monastic complexes, a courtesan giving to a Jain complex, and royal women giving to Buddhist complexes" (p. 93). The author examines the many "examples of matronage from Buddhist, Jain, and Muslim sites" (p. 94). Findly concludes that "[n]ot only have women given, historically, and been named as givers, but they have represented themselves in ways reflective of their peculiar social roles within the prevailing culture" (p. 112). In this case women found political and social agency through their architectural expressions.

Kishwar Rizvi, in the chapter entitled Gendered Patronage: women and benevolence during the early Safavid Empire, concentrates on the patronage and the political agency (referring to the women's participation in the political arena) of the royal women of the Safavid dynasty in Tabriz, Iran. Rizvi challenges the conclusions of Maria Szuppe's study of Safavid royal women. Specifically, Szuppe concludes that the independence of such royal women was attributed to their "pagan social mores, which were not as restrictive as the Islamic ones" (p. 124). Rizvi points out that such a conclusion is inadequate, since it does not account for the influence of Islam in the patronage and agency of royal women. Concentrating on the Fatima al-Ma'suma in Qum, Rizvi points out that this shrine is "an important window onto the cultural involvement of women of the Safavid house and their patronage during the early Safavid era" (145).

Nancy Micklewright, in the chapter entitled Public and Private for Ottoman Women of the Nineteenth Century, examines the costumes of nineteenth-century 
Ottoman elite women as a window to their social and political agency. The conceptual framework of her analysis rests on the following premises: (1) "[c]lothing choices demonstrate the identification, real or desired, with particular groups" and (2) "[s]pecific modes of dress are understood by those within a fashion system to signal power and status" (p. 156). In her examination of elite Ottoman women Micklewright concludes that not only were women active agents in society, but they "could be patrons of significant public architecture and could wield considerable political influence" (p. 171). This, the author argues, was reflective in the elaborate costumes the women wore.

Elizabeth Brown Frierson, in the chapter entitled Mirrors Out, Mirrors In: domestication and rejection of the foreign in late-Ottoman women's magazines (18751908), examines how literature concerned with the West was used to affirm an Islamic Ottoman identity in magazines written and read by women in the late nineteenth century Ottoman society. Hence, Frierson points out that "[u]ltimately, discussions of the foreign abroad were also critiques of the foreign within" (p. 178). What is particularly interesting in Frierson's analysis is the fact that while the early Ottoman woman's press was a product of elite women - "wives and daughter of high civic officials" (181) - later publications were a product of non-elite women; the latter emphasis represents a slight departure from the focus on elite women by the other authors in the book. The author concludes that the critical analysis of the foreign mores, as featured in the women's magazines, was used both as introspection on the society's Ottoman identity as well as a rejection of the 'West'. Women's political and social expressions in these magazines is indeed indicative of their agency in the Ottoman society.

Finally, Salah Hassan, in the chapter entitled Nothing Romantic About It! A critique of orientalist representation in the installations of Houria Niati, sheds light on Houria Niati's criticism of the imagery of Algerian women in the eyes of French colonial male observers. With intriguing visuals, the author points out that Niati's criticism of the depiction of Algerian women, a "product of a western male visual system" (p. 205), marginalized Algerian women not only based on their gender but also based on the 'other' that Algerian women represented to the colonial observers. In this way, the author points out that Niati, as an artist, "used her work to critique the politically repressive role of the colonial and gendered gaze, which, in Africa, the Middle East, and Asia, combined to dehumanize the subject nation, and thus to intellectualize and disapprove it, while humanizing the colonial power, thus asserting the superior strength, rationality, and justice of the European nations" (p. 206).

Irm Haleem

Ph.D. Lecturer,

Department of Political Science

Northeastern University. 